\title{
Dampak Pertumbuhan Ekonomi, Aglomerasi, dan Modal Manusia Terhadap Ketimpangan Pendapatan Antar Kabupaten/Kota Di Provinsi Kalimantan Barat Jurnal Ecces
}

\author{
Hendarmin ${ }^{1}$ \\ ${ }^{1}$ Program Studi Ekonomi Pembangunan \\ Fakultas Ekonomi dan Bisnis Universitas Tanjungpura Pontianak \\ Jl. Prof. Dr. H. Hadari Nawawi Pontianak 78124 \\ E-mail : hendarmin_feuntan@ymail.com
}

\section{Abstrak: Dampak Pertumbuhan Ekonomi, Aglomerasi, dan Modal Manusia Terhadap Ketimpangan Pendaparan Antar Kabupaten/Kota di Provinsi Kalimantan Barat}

Kondisi pertumbuhan ekonomi dan ketimpangan pendapatan di Provinsi Kalimantan Barat selama 10 tahun terakhir mengalami tren perkembangan yang fluktuatif. Beberapa daerah di Kabupaten/Kota memperlihatkan pertumbuhan ekonomi yang meningkat diikuti dengan gini rasio yang meningkat, namun ada juga penurunan pertumbuhan ekonomi diikuti dengan penurunan ketimpangan pendapatan. Ini mengindikasikan bahwa daerah Provinsi Kalimantan Barat masih mengalami tingkat kesejahteraan yang belum merata. Penelitian ini bertujuan mengetahui pengaruh pertumbuhan ekonomi, aglomerasi, dan modal manusia terhadap ketimpangan pendapatan di Kabupaten/Kota Provinsi Kalimantan Barat. Analisis data menggunakan regresi data panel selama kurun waktu 2013-2017 dan data cross section 14 Kabupaten/Kota di Provinsi Kalimantan Barat. Hasil penelitian yang diperoleh dari regresi data panel pendekatan fixed effect ditemukan bahwa secara parsial variabel pertumbuhan ekonomi berpengaruh positif dan tidak signifikan, variabel aglomerasi berpengaruh negatif dan tidak signifikan, sedangkan variabel modal manusia yang diproksi dengan IPM berpengaruh positif dan signifikan terhadap ketimpangan pendapatan antar Kabupaten/Kota di Provinsi Kalimantan Barat. Variabel pertumbuhan ekonomi, aglomerasi dan modal manusia secara simultan berpengaruh terhadap ketimpangan pendapatan antar Kabupaten/Kota di Provinsi Kalimantan Barat. Perlu adanya penyediaan pelayanan publik agar kesenjangan antar daerah kota dan kabupaten tidak semakin lebar. Tujuan pembangunan tidak semata berorientasi pada mengejar pertumbuhan yang tinggi tetapi juga harus mempertimbangkan pemerataan dan kesejahteraan.

Kata kunci: Ketimpangan Pendapatan, Pertumbuhan Ekonomi, Aglomerasi, dan Modal Manusia. 


\section{Abstract : The Impact of Economic Growth, Agglomeration, and Human Capital on Income Inequality between Regencies/Cities In West Kalimantan Province}

The condition of economic growth and income inequality in West Kalimantan Province over the past ten years has experienced a fluctuating development trend. Some regions in the regencies/cities show an increase in economic growth, followed by an increasing Gini ratio. Still, there is also a decline in economic growth, followed by a decrease in income inequality. This indicates that the area of West Kalimantan Province is still experiencing an uneven level of welfare. This study aims to determine the effect of economic growth, agglomeration, and human capital on income inequality in the regencies/cities of West Kalimantan Province. Data analysis used a fixed effect approach for panel data regression for the period 2013-2017 and cross-section data of 14 districts/cities in West Kalimantan Province. The results showed that partially, the economic growth variable had a positive and not significant effect, the agglomeration variable had a negative and not significant effect, while the human capital variable, which was proxied by HDI, had a positive and significant effect on income inequality between regencies/cities in West Kalimantan Province. The variables of economic growth, agglomeration, and human capital simultaneously influence income inequality between regencies/cities in West Kalimantan Province. It is necessary to provide public services so that the gap between the city and district areas does not widen. The purpose of development is not merely oriented towards the pursuit of high growth but must also consider equity and prosperity.

Keywords: Income Inequality, Economic Growth, Agglomeration, and Human Capital

\section{PENDAHULUAN / INTRODUCTION}

Di beberapa negara berkembangan termasuk di Indonesia, masih ada anggapan bahwa pertumbuhan ekonomi yang dicapai dengan pesat menjadi salah satu syarat untuk mencapai kesejahteraan masyarakat yang lebih merata. Upaya pemerintah dalam meningkatkan kesejahteraan masyarakat, tercermin dari kualitas pertumbuhan ekonomi yang dapat dicapai. Semakin tinggi tingkat pertumbuhan ekonomi, berarti semakin baik pula tingkat pemerataan pendapatan di masyarakat (Amri, 2017). Namun, pada kenyataannya pertumbuhan ekonomi yang dicapai suatu daerah, bukanlah satu-satunya indikator untuk mengukur keberhasilan pembangunan. Kondisi ini dapat diketahui secara empiris di negaranegara berkembang, yang menyatakan bahwa pertumbuhan ekonomi yang tinggi pada awalnya akan berdampak pada peningkatan ketimpangan pendapatan, ini mengandung arti bahwa bagi daerah yang mempunyai tingkat pertumbuhan ekonomi yang pesat pada umumnya diikuti dengan distribusi pendapatan yang makin timpang. Secara umum ketimpangan yang terjadi di berbagai daerah, hanya menggambarkan ketimpangan pendapatan yang menyebabkan jurang perbedaan (gap) antara orang kaya dan orang miskin, dan ketimpangan spasial yang berdampak adanya daerah yang cepat maju dan 
daerah yang lambat dalam mencapai pertumbuhan ekonominya, serta ketimpangan antar sektor yang juga berdampak adanya daerah yang memiliki sektor basis dan non basis.

Dengan melihat kondisi di atas, tidaklah mengherankan bila masih ada daerah-daerah yang terdapat wilayah maju dan wilayah tertingga, sebagaimana kondisi di kabupaten Kota di Provinsi Kalimantan Barat. Untuk mengukur kemajuan dalam ekonomi di kabupaten kota Provinsi Kalimantan Barat, salah satu indikator yang digunakan adalah pendapan perkapita, yang secara agregat dapat menjelaskan tentang seberapa besar tingkat kesejahteraan yang dapat dicapai oleh masyarakat daerah tersebut. Secara umum, berdasarkan data BPS pada tabel 1 memperlihatkan bahwa daerah kabupaten/kota, yaitu Kota Pontianak sebagai ibukota Kalimantan Barat mendominasi perekonomian Provinsi Kalimantan Barat. Sampai tahun 2017 Kota Pontianak memberikan kontribusi hampir 19 persen terhadap total PDRB kabupaten/kota seKalimantan Barat. Dua kabupaten lain yang memberikan kontribusi cukup besar juga adalah Kabupaten Kubu Raya (12,92 persen) dan Kabupaten Ketapang (12,23 persen).

Tabel 1

Kontribusi PDRB, Pertumbuhan Ekonomi dan PDRB Perkapita Menurut Kabupaten/Kota Di Provinsi Kalimantan Barat, 2017

\begin{tabular}{lccc}
\hline Kabupaten/Kota & $\begin{array}{c}\text { Kontribusi } \\
\text { PDRB (\%) }\end{array}$ & $\begin{array}{c}\text { Pertumbuhan } \\
\text { Ekonomi (\%) }\end{array}$ & $\begin{array}{c}\text { PDRB Per } \\
\text { Kapita } \\
\text { (juta rupiah) }\end{array}$ \\
\hline Kab. Sambas & 9,80 & 5,25 & 30,45 \\
Kab. Bengkayang & 4,11 & 5,15 & 27,72 \\
Kab. Landak & 5,01 & 5,28 & 22,59 \\
Kab. Mempawah & 3,86 & 5,99 & 24,77 \\
Kab. Sanggau & 9,46 & 5,35 & 34,30 \\
Kab. Ketapang & 12,23 & 7,97 & 41,27 \\
Kab. Sintang & 6,86 & 5,28 & 27,89 \\
Kab. Kapuas Hulu & 4,79 & 5,28 & 31,32 \\
Kab. Sekadau & 2,94 & 5,93 & 24,58 \\
Kab. Melawi & 2,45 & 4,75 & 20,12 \\
Kab. Kayong Utara & 1,93 & 5,98 & 29,39 \\
Kab. Kubu Raya & 12,92 & 6,37 & 38,11 \\
Kota Pontianak & 18,62 & 5,10 & 49,36 \\
Kota Singkawang & 5,03 & 5,17 & 38,91 \\
\hline Sumber: BPS, PDRB Kabupaten/Kota Provinsi Kalimantan Barat, 2013-2017
\end{tabular}

Ketimpangan terlihat jelas pada indikator PDRB per kapita. Setiap penduduk di kota Pontianak bisa menghasilkan 49,36 juta rupiah per tahun. Disusul oleh penduduk kota Singkawang yang bisa menghasilkan 38,91 juta rupiah per tahun. Hal ini tidak sebanding dengan penduduk yang ada di kabupaten Landak dan Melawi dimana PDRB per kapitanya 
tidak sampai separuh dari PDRB per kapita kota Pontianak yaitu 22,59 juta rupiah per tahun dan 20,12 juta rupiah per tahun.

Berbagai studi menggambarkan keterkaitan antara pertumbuhan ekonomi dengan ketimpangan pendapatan yang mengindikasikan adanya hubungan yang negatif bahkan ada yang positif. Oleh karena itu kita dapat mengetahui bagaimana kondisi pertumbuhan ekonomi dan kaitannya dengan ketimpangan pendapatan yang terjadi selama tahun 20082017 di provinsi Kalimantan Barat berdasarkan pada gambar di bawah ini :

Gambar 1

Perbandingan Pertumbuhan Ekonomi dengan Ketimpangan Pendapatan

di Provinsi Kalimantan Barat Tahun 2008-2017

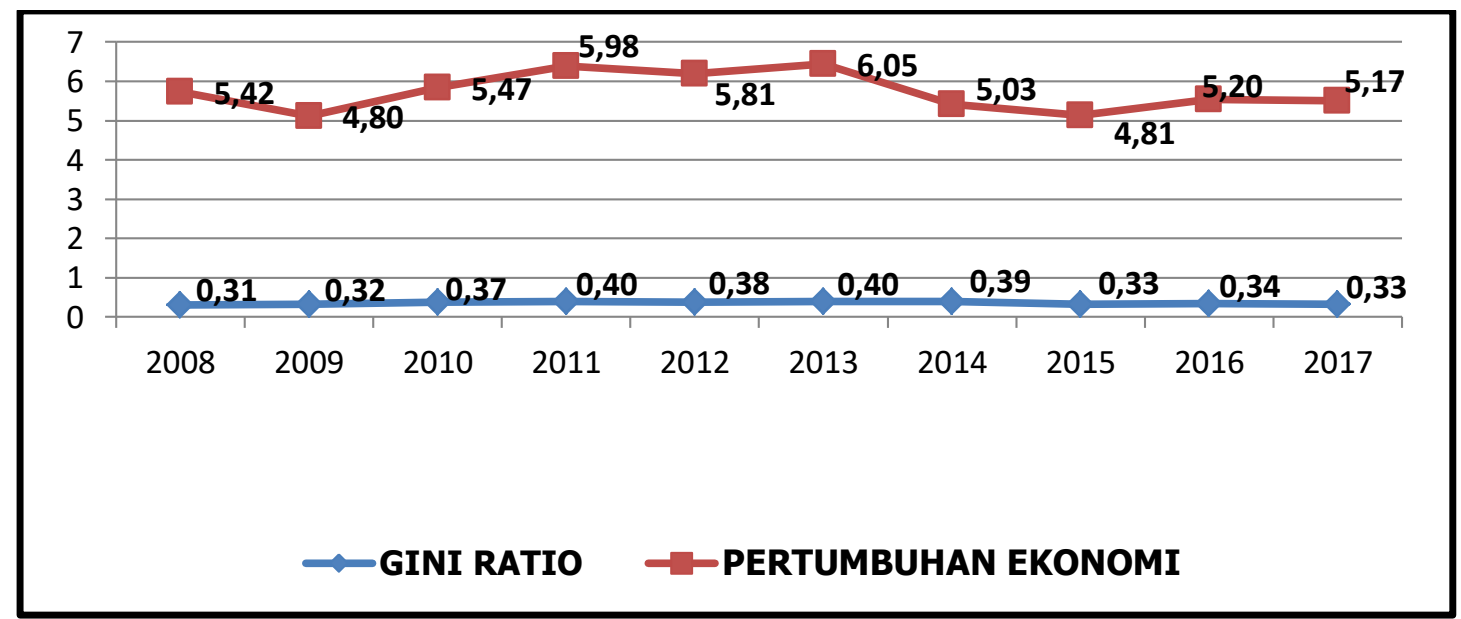

Sumber : BPS, Kalimantan Barat Dalam Angka, Berbagai Penerbitan.

Koefisien gini di Provinsi Kalimantan Barat berfluktuasi selama 10 tahun terakhir. Dari gambar 1 di atas dapat kita lihat perkembangan gini ratio, dimana angka gini ratio tersebut mengindikasikan perubahan-perubahan tingkat ketimpangan setiap tahunnya. Seperti yang terjadi pada tahun 2008-2011 terjadi peningkatan gini ratio secara berkala walaupun pada 2012 mengalami penurunan, namun secara keseluruhan peningkatan dan penurunan ketimpangan di Kalimantan Barat selama 10 tahun terakhir hanya mengalami perubahanperubahan ketimpangan yang sangat kecil, misalnya di tahun 2013 gini ratio dari 0,40 turun menjadi 0,39 di tahun 2014 atau turun sebesar 0,01 poin, dan turun kembali sebesar 0,06 menjadi 0,33 di tahun 2015, dan naik kembali sebesar 0,01 menjadi 0,34 di tahun 2016 sedangkan di tahun terakhir 2017 kembali turun sebesar 0,01 menjadi 0,33. Walaupun demikian, perubahan-perubahan yang terjadi dari angka gini ratio di Kalimantan Barat selama periode 2008-2017 tersebut masih tergolong pada tingkat ketimpangan pendapatan yang relatif sedang.

Secara teoritis dalam kenyataannya bahwa beberapa daerah menghadapi kondisi yang searah antara pertumbuhan ekonomi dan ketimpangan pendapatan. Pada tahun 2009- 
2011 kita melihat sebuah fenomena dimana pertumbuhan ekonomi yang menunjukkan tren peningkatan diikuti dengan ketimpangan pendapatan yang relatif meningkat, dan di tahun berikutnya 2013-2015 pertumbuhan ekonomi turun diikuti dengan ketimpangan yang turun, walaupun terjadi kenaikan sedikit di tahun 2016 sebesar 0,01 poin. Hingga tahun 2017 masih memperlihatkan angka penurunan pada gini ratio yang turunya sama dengan tahuntahun sebelumnya. ini mengindikasikan bahwa di daerah Provinsi Kalimantan Barat mengalami kondisi dimana kesejahteraan masyarakat belum merata.

Banyak studi empiris yang meneliti pengaruh variabel pertumbuhan ekonomi dan ketimpangan pendapatan. Akan tetapi pengaruh dari kedua variabel tersebut banyak menimbulkan hasil penelitian yang beragam (Turnovsky, 2015). Artinya, pengaruh antara pertumbuhan ekonomi dan ketimpangan pendapatan masih sulit untuk dipahami dan menjadi hal yang bertentangan di beberapa penelitian empiris di dunia (Yang \& Greaney, 2016). Bahkan ada tiga pendapat yang berbeda terkait dengan pengaruh kedua variabel pertumbuhan ekonomi dan ketimpangan pendapatan yang hasilnya berdampak positif negatif (Kurniasih, 2013) dan non linier (Charless-Coll, 2013).

Beberapa penelitian menemukan pengaruh yang positif antara variabel pertumbuhan ekonomi dan ketimpangan pendapatan. Seperti studi yang dilakukan Chamber (2010), Wahiba \& EI Weriemmi (2014) dan Rubin \& Segal (2015) yang menyimpulkan bahwa pertumbuhan ekonomi berpengaruh positif terhadap ketimpangan pendapatan. Begitu pula studi dari Lundberg \& Squire (2003) yang menemukan hasil yang sama dimana peningkatan pertumbuhan ekonomi dapat meningkatkan ketimpangan pendapatan, yang berarti semakin tinggi pertumbuhan ekonomi berdampak pada semakin tinggi pula ketimpangan pendapatan. Dan sebaliknya penurunan pertumbuhan ekonomi menyebabkan pula penurunan ketimpangan pendapatan. Berbeda dengan hasil studi dari Panizza (2002) yang menemukan adanya hubungan negatif antara ketimpangan pendapatan dengan pertumbuhan ekonomi. Dimana pertumbuhan ekonomi dapat menurunkan ketimpangan pendapatan (Nissim, 2007). Pertumbuhan ekonomi berpengaruh negatif terhadap ketimpangan pendapatan dan tidak signifikan (Binatli, 2012).

Adanya pengaruh yang positif dan negatif antara variabel pertumbuhan ekonomi terhadap ketimpangan pendapatan menunjukkan bahwa pertumbuhan ekonomi terkadang dapat berdampak baik dan buruk pada pemerataan pendapatan di setiap wilayah . Hal ini sesuai dengan pernyataan Kuznets (1955) bahwa hubungan antara pertumbuhan ekonomi dengan ketimpangan pendapatan berbentuk huruf $U$ terbalik, yang mana pada awalnya kenaikan pertumbuhan ekonomi dapat meningkatkan ketimpangan pendapatan, namun 
setelah mencapai kondisi tertentu peningkatan pertumbuhan ekonomi justru akan menurunkan ketimpangan pendapatan. Studi empiris dari Huang et.al (2015) ditemukan bahwa pengaruh antara pertumbuhan ekonomi dan ketimpangan pendapatan bisa positif dan negatif. Di negara berpendapatan rendah terdapat pengaruh negatif antara ketimpangan pendapatan dan pertumbuhan ekonomi, namun sebaliknya di negara dengan pendapatan tinggi terdapat pengaruh positif antara ketimpangan dengan pertumbuhan ekonomi (Fawaz et.al, 2014). Hassan, Zaman \& Gul (2015) dalam penelitian mereka di Pakistan menyajikan bukti empiris bahwa dalam jangka pendek terdapat hubungan positif antara pertumbuhan ekonomi dan ketimpangan pendapatan. Sedangkan dalam jangka panjang, terdapat hubungan negatif antara kedua variabel tersebut. Berbeda dengan Hassan, Zaman dan Gul, penelitian Risso \& Carrera (2012) justru menyimpulkan bahwa dalam jangka panjang hubungan antara pertumbuhan ekonomi dan ketimpangan pendapatan adalah positif dan signifikan.

Selain itu, beberapa faktor yang menyebabkan ketimpangan terjadi di provinsi dan juga di daerah Kabupaten dan Kota adalah adanya struktur perekonomian di setiap daerah yang sangat berbeda. Dimana pada umumnya perekonomian Kota didominasi oleh kegiatan industri, perdagangan dan jasa, sedangkan perekonomian Kabupaten cenderung didominasi oleh kegiatan di sektor primer (kegiatan pertanian dalam arti luas, termasuk tanaman pangan, perkebunan, peternakan, perikanan dan kehutanan), keterbatasan sumber daya yang dimiliki, rendahnya akses masyarakat terhadap fasilitas pendidikan dan kesehatan yang berakibat pada rendahnya kualitas indeks pembangunan manusia (IPM) serta jumlah dan kualitas infrastruktur baik sarana dan prasarana yang masih buruk dikarenakan alokasi anggaran yang masih kurang untuk pembangunan dan pemeliharaan. Menurut Badriah, Sambodo \& Suryahan (2006) Ketimpangan bisa terjadi dalam proses pembangunan daerah karena perbedaan potensi dan karakteristik sumberdaya alam, sumber daya manusia, arus modal, kebijakan pembangunan pemerintah pusat yang kurang berpihak kepada wilayah tertentu, dan adanya perencanaan daerah yang kurang tepat.

Sebagaimana yang telah dijelaskan sebelumnya, bahwa tingkat pertumbuhan ekonomi dan ketimpangan pendapatan yang diproksi dengan gini rasio menggambarkan di masing-masing daerah Kabupaten/Kota Provinsi Kalimantan Barat menunjukkan perkembangan yang berbeda-beda. Secara umum data pertumbuhan ekonomi di setiap daerah memperlihatkan tren yang meningkat yang ditandai dengan peningkatan pada pendapatan perkapita riil. Hal ini berarti adanya peningkatan kesejahteraan masyarakat secara umum, akan tetapi pertumbuhan ekonomi seharusnya diikuti dengan ketimpangan pendapatan yang lebih merata sehingga dapat mengurangi kesenjangan ( $g a p$ ) antara orang 250 
kaya dan miskin. Dengan demikian, tujuan penelitian ini adalah untuk mengatahui dan menganalisis pengaruh pertumbuhan ekonomi, aglomerasi dan modal manusia terhadap ketimpangan pendapatan antar Kabupaten/Kota di Provinsi Kalimantan Barat.

\section{TINJAUAN TEORITIK / LITERATURE REVIEW}

\section{Ketimpangan Pendapatan Antar Daerah}

Secara teoritis, permasalahan ketimpangan antar wilayah mula-mula dimunculkan oleh Douglas C. North (1955) dalam analisanya tentang teori pertumbuhan neo klasik. Dalam teori tersebut, dimunculkan sebuah prediksi tentang hubungan antara tingkat pembangunan ekonomi nasional suatu negara dengan ketimpangan pembangunan antar wilayah. Hipotesa ini kemudian lebih dikenal sebagai hipotesa neo-klasik. Menurut hipotesa neo-klasik, pada permulaan proses pembangunan suatu negara, ketimpangan pembangunan antar wilayah cenderung meningkat. Proses ini akan terjadi sampai ketimpangan tersebut mencapai titik puncak. Setelah itu, bila proses pembangunan terus berlanjut maka secara berangsur-angsur ketimpangan pembangunan antar wilayah tersebut akan menurun. Berdasarkan hipotesa ini, bahwa pada negara-negara sedang berkembang umumnya ketimpangan pembangunan antar wilayah cenderung lebih tinggi, sedangkan pada negara maju ketimpangan tersebut akan menjadi lebih rendah. Dengan kata lain, kurva ketimpangan antar wilayah adalah berbentuk huruf $U$ terbalik.

Kebenaran hipotesa neo-klasik ini kemudian diuji kebenarannya oleh Williamson pada tahun 1965 melalui studi tentang ketimpangan pembangunan antar wilayah pada negara maju dan negara sedang berkembang dengan menggunakan data time series dan cross section. Williamson (1965) dalam Sjafrizal (2008) menjadi orang pertama yang mencoba membuktikan hipotesis $U$ terbalik dengan menggunakan data antar wilayah. Dengan mendasarkan analisisnya pada pengalaman empiris di 24 negara selama kurun waktu 1950-1960, ia membuktikan bahwa kesenjangan antar wilayah akan memberikan pengaruh negatif pada kelangsungan pertumbuhan ekonomi. Hasil penelitian tersebut menunjukkan bahwa hipotesa neo-klasik yang diformulasi secara teoritis, ternyata terbukti benar secara empirik. Ini berarti bahwa proses pembangunan suatu negara tidak otomatis dapat menurunkan ketimpangan pembangunan antar wilayah, tetapi pada tahap permulaan justru terjadi hal yang sebaliknya.

Berdasarkan hipotesis neo-klasik terlihat bahwa variabel yang berpengaruh terhadap ketimpangan pembangunan antar daerah adalah tingkat pembangunan suatu wilayah. Tingkat pembangunan tersebut biasanya diwakili oleh pendapatan negara bersangkutan. 
Sjafrizal (2018) menyatakan bahwa hubungan fungsional antar variabel ini dengan ketimpangan ekonomi regional adalah bersifat positif di negara berkembang (pada awal proses pembangunan nasional) dan negatif pada negara maju (pada saat proses pembangunan sudah lama dilaksanakan). Bila hubungan tersebut bersifat positif berarti bahwa peningkatan pembangunan nasional akan meningkat pula ketimpangan pendapatan antar daerah. Sebaliknya apabila hubungan tersebut negatif, berarti bahwa peningkatan pembangunan ekonomi akan cenderung mengurangi ketimpangan pendapatan antar daerah.

Pola hubungan positif dan negatif dari variabel di atas mengindikasikan belum adanya konsistensi hasil penelitian terkait dengan hubungan pertumbuhan ekonomi dan ketimpangan pendapatan. Namun beberapa kajian empiris membuktikan adanya hubungan kausalitas antara ketimpangan pendapatan dengan pertumbuhan ekonomi dapat terjadi dalam bentuk dua arah maupun satu arah. Alawin, Siam \& Al-Hamdi (2013) dalam studinya di Yordania menemukan adanya hubungan satu arah dari ketimpangan pendapatan ke pertumbuhan ekonomi. Begitu pula dengan penelitian Baharuddin et al. (2016) di negaranegara Asean menyimpulkan adanya hubungan satu arah dari ketimpangan pendapatan terhadap pertumbuhan ekonomi. Sebaliknya, Das, Sinha \& Mitra (2014) justru mememukan adanya hubungan satu arah dari pertumbuhan ekonomi terhadap ketimpangan pendapatan. Terakhir, penelitian yang dilakukan oleh Yang \& Greaney (2016) menyimpulkan adanya hubungan dua arah antara ketimpangan dan pertumbuhan ekonomi.

\section{Penyebab Ketimpangan Ekonomi Antar Wilayah}

Menurut (Sjafrizal; 2017) beberapa faktor utama yang menyebabkan terjadinya ketimpangan ekonomi antar wilayah adalaha sebagai berikut : (1) Perbedaan kandungan sumber daya alam; (2) Perbedaan kondisi demografis; (3) Kurang lancarna mobilitas barang dan jasa; (4) Konsentrasi kegiatan ekonomi wilayah; dan (5) Daerah yang mendapatkan alokasi investasi yang lebih besar dari pemerintah, atau dapat menarik lebih banyak investasi swasta ke daerahnya akan cenderung mempunyai tingkat pertumbuhan ekonomi yang lebih cepat.

\section{Keterkaitan Pertumbuhan Ekonomi Terhadap Ketimpangan Pendapatan}

Kuznets (1955) meneliti hubungan antara pertumbuhan ekonomi dengan ketimpangan pendapatan. Ditemukan, ada suatu hubungan antara pertumbuhan ekonomi dengan ketimpangan pendapatan. Berdasarkan hipotesis ini ketimpangan pendapatan dalam suatu negara akan meningkat pada tahap awal pertumbuhan ekonomi, kemudian pada tahap menengah cenderung tidak berubah dan akhirnya menurun ketika negara tersebut sejahtera. Ketimpangan pendapatan yang besar pada fase awal pertumbuhan ekonomi ini disebabkan proses perubahan menjadi masyarakat industri. 
Kuznets juga mengemukakan bahwa ketimpangan pendapatan yang besar terjadi pada negara-negara yang belum berkembang berkaitan dengan rata-rata pendapatan per kapita yang lebih rendah. Kuznets mengasumsikan bahwa ketimpangan pendapatan ada bersama dengan tingkat pertumbuhan pendapatan per kapita yang rendah, dan hipotesis Kuznets tentang penyebab perubahan jangka panjang dalam distribusi pendapatan apakah ketidaksetaraan dalam distribusi pendapatan meningkat atau menurun dalam perjalanan pertumbuhan ekonomi bagi suatu negara hanya dapat dijelaskan 5 persen informasi empiris dan 95 persen hanya spekulasi dan kemungkinan harapan. Kuznets mengemukakan enam karakteristik atau ciri proses pertumbuhan ekonomi yang ditemui hampir diseluruh negara maju, yaitu : (1) tingkat pertumbuhan output perkapita dan pertumbuhan penduduk yang tinggi; (2) tingkat kenaikan produktifitas faktor total yang tinggi; (3) tingkat transformasi struktural ekonomi yang tinggi; (4) tingkat transformasi sosial dan ideologi yang tinggi; (5) adanya kecendrungan negara-negara yang mulai atau sudah maju perekonomiannya untuk berusaha merambah bagian-bagian dunia lainnya sebagai daerah pemasaran dan sumber bahan baku yang baru; dan (6) terbatasnya penyebaran pertumbuhan ekonomi yang hanya mencapai sepertiga bagian penduduk dunia.

\section{Keterkaitan Aglomerasi Terhadap Ketimpangan Pendapatan}

Menurut Sjafrizal (2018) menyatakan bahwa ada beberapa faktor lain yang dapat berpengaruh terhadap perubahan ketimpangan pembangunan antar daerah. Faktor-faktor tersebut antara lain konsentrasi kegiatan ekonomi antar daerah, mobilitas barang (perdagangan) dan faktor produksi antar daerah serta alokasi investasi (pemerintan dan swasta) antar daerah, bahkan kebijakan pembangunan daerah yang dilakukan oleh suatu daerah dapat pula mempengaruhi ketimpangan pembangunan daerah yang bersangkutan. Konsentrasi kegiatan ekonomi antar daerah yang cukup tinggi akan mendorong meningkatnya ketimpangan pembangunan antar daerah karena proses pembangunan daerah akan lebih cepat pada daerah yang konsentrasi kegiatan ekonominya tergolong tinggi. Demikian pula sebaliknya, terjadi pada daerah dengan konsentrasi kegiatan ekonomii yang lebih rendah.

Aglomerasi (pemusatan aktivitas) produksi digunakan oleh Bonet (2006) sebagai salah satu variabel yang mempengaruhi kesenjangan wilayah. Ia menyatakan bahwa aglomerasi produksi dapat mempengaruhi kesenjangan wilayah secara langsung, yaitu pada saat terdapat hambatan bagi mobilitas tenaga kerja antar wilayah, atau saat terdapat surplus tenaga kerja dalam perekonomian. 
Kuncoro (2004), menyatakan bahwa perbedaan antar daerah tersebut yang menjadi kendala dalam pemerataan pembangunan ekonomi dikarenakan terpusatnya (konsentrasi) suatu kegiatan perekonomian yang berdampak pada meningkatnya pertumbuhan ekonomi dibeberapa wilayah yang memiliki sumber daya alam melimpah. Kekayaan alam yang dimiliki seharusnya dapat menjadi nilai tambah dalam meningkatkan pembangunan ekonomi. Keunggulan yang dimiliki tersebut diharapkan dapat memberikan dampak menyebar (spread effect). Namun kekayaan alam ini, tidak dimiliki oleh semua daerah di seluruh Indonesia secara merata. Keadaan seperti itulah yang menyebabkan timbulnya ketimpangan antar daerah.

Studi dari Syamsir dan Rahman (2018), mengatakan bahwa terjadinya konsentrasi kegiatan ekonomi yang cukup tinggi pada wilayah tertentu jelas akan mempengaruhi ketimpangan pembangunan antar wilayah. Konsentrasi ekonomi ini tercermin dalam kegiatan aglomerasi. Pertumbuhan ekonomi daerah akan cendeung lebih cepat pada daerah dimana terdapat konsentrasi kegiatan ekonomi yang cukup besar.

Sampai sekarang, berbagai penelitian tentang keterkaitan aglomerasi, pertumbuhan ekonomi dan ketimpangan pendapatan sudah ada di berbagai negara. Hasil penelitian ini dapat membenarkan hubungan antara aglomerasi dan ketimpangan pendapatan yang terjadi di berbagai negara (Frazer, 2006; Geppert \& Stephan, 2008); dan Ha Ming, Le Dang \& KienTrung (2019) yang menyimpulkan bahwa dampak dari konsentrasi kegiatan ekonomi dapat mengurangi ketimpangan pendapatan. Berdasarkan hubungan antara pertumbuhan ekonomi dan penelitian ketimpangan pendapatan yang dilakukan oleh Mukhlis dan Simanjuntak (2016); menemukan hubungan antara pertumbuhan ekonomi dan tingkat kemiskinan.

\section{Keterkaitan Modal Manusia Terhadap Ketimpangan Pendapatan}

Banyak kalangan ekonom berpendapat bahwa pengembangan dari modal manusia (pendidikan) pada semua tingkat merupakan salah satu unsur penting dalam mendorong proses pembangunan, baik pada tingkat nasional maupun pada tingkat daerah. Pertimbangannya adalah karena modal manusia (pendidikan) akan dapat mendorong peningkatan skil tenaga kerja yang selanjutnya akan meningkatkan produktivitas tenaga kerja. Oleh karena itu, melalui pengembangan pada bidang pendidikan akan dapat mendorong proses inovasi dan perbaikan teknologi produksi yang selanjutnya dapat mendorong perbaikan tingkat efisiensi usaha. Berangkat dari pandangan tersebut di atas, pengembangan pendidikan pada daerah yang relatif terbelang diperkirakan akan merupakan kebijakan yang cukup penting untuk mengurangi ketimpangan pendapatan antar daerah.

Beberapa penelitian menekankan modal manusia sebagai salah satu faktor utama yang mempengaruhi tingkat ketimpangan pendapatan. Modal manusia, diukur dengan 254 
pencapaian pendidikan yang diwujudkan dalam seseorang yang bekerja. Kebijakan pemerintah dalam menggunakan anggaran untuk pengeluaran bidang pendidikan yang lebih tinggi bertujuan sebagai alat yang efektif untuk mengurangi ketimpangan pendidikan dan juga dalam rangka memperkecil ketimpangan pendapatan antar daerah. Modal manusia menunjukkan bahwa tingkat dan distribusi sekolah untuk seluruh penduduk menentukan distribusi pendapatan (Backer \& Chiswick 1966; Mincer 1974). Oleh karena itu, dalam model memperkirakan bahwa penawaran dan permintaan orang yang berpendidikan mempengaruhi ketimpangan pendapatan dalam masyarakat. Sementara itu modal manusia menjelaskan hubungan positif antara ketimpangan pendidikan yang diukur dengan variasi tingkat sekolah, rata-rata sekolah terhadap ketimpangan pendapatan bisa positif dan negatif.

Selama beberapa tahun terakhir, masalah hubungan sebab akibat antara kemiskinan dan pendidikan, dan dampak dari kegiatan pelatihan dan pendidikan terhadap distribusi pendapatan telah menjadi perhatian oleh para ekonom. Dalam hal ini, para penentang teori human capital percaya bahwa cara terbaik untuk meningkatkan pemerataan pendapatan dalam jangka panjang adalah dengan berinvestasi pada modal manusia. Becker \& Chiswick (1966) menyakini bahwa berinvestasi dalam pendidikan dapat menghasilkan keseimbangan dalam pemerataan pendapatan yang lebih baik. Di sisi lain, menggunakan fungsi pendapatan, Mincer (1970) berpendapat bahwa selain pendapatan dasar, yang tidak tergantung pada pendidikan, pendapatan setiap orang dipengaruhi oleh investasi pada pendidikan. Ketika tingkat investasi dalam pendidikan dan tingkat hasilnya meninkat, maka pendapatan pribadinya pun juga ikut meningkat.

Penelitian yang dilakukan oleh Alvan (2007) dan Shahabadi, Nemati, \& Hosseinidoust, (2018) yang mengatakan bahwa untuk mencapai GDP dan pendapatan perkapita yang lebih tinggi, serta tingkat kesenjangan yang lebih rendah, indeks pembangunan manusia sebaiknya diprioritaskan dalam program pembangunan suatu negara maupun daerah. Tingginya nilai indeks pembangunan manusia (modal manusia) ini akan berdampak positif terhadap distribusi pendapatan, sehingga semakin baik nilai indeks pembangunan manusia, maka semakin rendah tingkat kesenjangan pendapatan suatu daerah. Begitu pula sebaliknya, semakin buruk nilai indeks pembangunan manusianya, maka semakin tinggi pula tingkat kesenjangan pendapatannya. Hal tersebut sesuai dengan teori human capital, yaitu bahwa peran modal manusia memiliki pengaruh terhadap pertumbuhan ekonomi dan akan mengurangi disparitas pendapatan karena pendidikan berperan di dalam meningkatkan produktivitas tenaga kerja. Teori ini menganggap pertumbuhan penduduk ditentukan oleh produktivitas perorangan. Jika setiap orang memiliki pendapatan yang lebih tinggi karena 
pendidikannya lebih tinggi, maka pertumbuhan ekonomi penduduk dapat ditunjang, dengan adanya pertumbuhan ekonomi baik secara langsung maupun tidak langsung akan berpengaruh negatif terhadap ketimpangan pendapatan. Oleh karena itu, untuk menekan tingkat kesenjangan pendapatan di suatu daerah maupun negara, Indeks Pembangunan Manusia (IPM) sangat penting untuk diperhatikan perannnya dalam menurunkan ketimpangan pendapatan antar wilayah/daerah. Beberapa studi menganalisis pengaruh pertumbuhan ekonomi, aglomerasi dan modal manusia terhadap ketimpangan pendapatan antar Kabupaten/Kota di Provinsi Kalimantan Barat, diantaranya adalah : Kuznets (1955); Bonet (2006); Frazer, G. (2006); Arzu (2007); Geppert, K., \& Stephan, A. (2008); Thomas (2009); Kurniasih (2013); Sabir, et.al. (2015); Ferdinand (2017); Mukhlis, Hidayah dan Sariyani (2018), Trimurti, et.al (2018), dalam kaitannya dengan penelitian tersebut diatas dapat disimpulkan bahwa faktor dari pertumbuhan ekonomi, aglomerasi dan modal manusia mempunyai dampak atau pengaruh positif maupun negatif terhadap ketimpangan di beberapa daerh atau negara, baik negara maju maupun negara-negara berkembang.

\section{METODE PENELITIAN / METHODS}

Penelitian ini bersifat kuantitatif. Penelitian kuantitatif merupakan metode penelitian untuk menguji teori-teori tertentu dengan cara meneliti hubungan antara variabel (Creswell, 2016). Adapun objek penelitian adalah provinsi di Provinsi Kalimantan Barat dengan analisis data menggunakan regresi data panel dengan kurun waktu selama 5 tahun (2013-2017) dan data cross section 14 Kabupaten/Kota di Provinsi Kalimantan Barat, sehingga observasi dalam penelitian ini berjumlah 70 sampel.

Data yang digunakan sebagai bahan analisis adalah data sekunder, yang berupa data panel, yaitu gabungan data time series tahun 2013-2017 dengan data cross section 14 Kabupaten/Kota di Provinsi Kalimantan Barat. Oleh karena itu teknik pengumpulan data dilakukan melalui kegiatan penelitian kepustakaan (library research) dari berbagai instansi yang dijadikan sumber data antara lain bersumber dari Badan Pusat Statistik, Bank Indonesia, Dinas Pendidikan Provinsi Kalimantan Barat, dan beberapa dokumen-dokumen yang berkaitan dengan data penelitian. Pengumpulan data dilakukan dengan cara mencatat ke dalam tabel-tabel atau daftar yang telah dipersiapkan sesuai dengan variabel-variabel yang terindentifikasi dalam kerangka analisis. Adapun data yang digunakan yaitu PDRB atas dasar harga konstan 2010, PDRB Perkapita atas dasar harga kosntan 2010, data aglomerasi produksi yang diperoleh dari PDRB Kabupaten/Kota dibagi dengan total PDRB Kalimantan 
Barat, dan data indeks pembangunan manusia (IPM) di Kabupaten/Kota Provinsi Kalimantan Barat.

Teknik analisis yang digunakan dalam penelitian ini adalah analisis statistik deskriptif dan analisis regersi. Analisis statistik deskriptif digunakan untuk menggambarkan atau menjelaskan fenomena-fenomena dari serangkaian data-data sekunder dalam penelitian ini, sedangkan analisis regresi digunakan untuk menjelaskan hubungan satu variabel dengan variabel lain dengan menggunakan metode Panel Least Square (PLS) menggunakan Program Eviews 9.0. Dalam penelitian ini model analisis data yang digunakan adalah model analisis regresi dengan metode data panel.

1. Estimasi Model Regresi Data Panel

Pada penelitian ini penulis mengembangkan estimasi model regresi data panel dengan melihat pengaruh pertumbuhan ekonomi (GRW), aglomerasi (AGL), dan modal manusia (IPM) terhadap ketimpangan pendapatan antar Kabupaten/Kota di Provinsi Kalimantan Barat kurun waktu 2013-2017.

Spesifikasi model yang digunakan diadopsi dari model yang telah digunakan dalam penelitian Mukhlis et.al (2018). Dengan mempertimbangkan paparan sebelumnya, model estimasi dalam penelitian ini adalah model regresi data panel. Berdasarkan teori, kerangka pemikiran dan hipotesis, serta penelitian terdahulu, maka akan dibuat model keterkaitan antara pertumbuhan ekonomi, aglomerasi ekonomi, dan modal manusia terhadap ketimpangan pendapatan di Kabupaten/Kota Provinsi Kalimantan Barat :

$$
G R=f(G R W, A G L, H C)
$$

Persamaan diatas dapat dinyatakan dalam spesifikasi model ekonometrika dalam persamaan regresi data panel, adalah sebagai berikut :

$$
\mathrm{GR}_{i t}=\alpha_{0}+\beta_{1} \mathrm{GRW}_{i t}+\beta_{2} \mathrm{AGL}_{i t}+\beta_{3} \mathrm{HC}_{i t}+\varepsilon_{i t}
$$

Dimana :

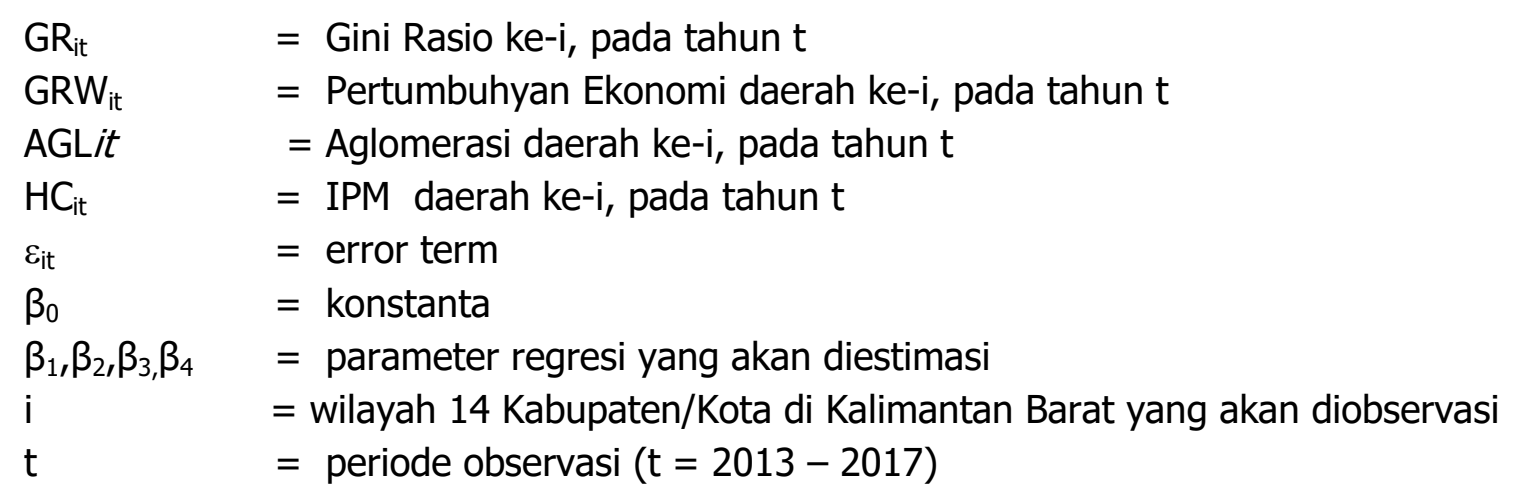

\section{Uji Spesifikasi Model \\ Uji Chow}


Uji Chow digunakan untuk menentukan model mana yang akan digunakan apakah Fixes Effect atau Common Effect dalam mengestimasi data panel. Kriteria yang digunakan untuk menarik kesimpulan pada uj chow adalah :

a. Jika nilai $\mathrm{F}$ hitung $>\mathrm{F}$ tabel, maka gunakan model fixes effect. Dan jika nilai $\mathrm{F}$ hitung $<\mathrm{F}$ tabel, maka gunakan model common effect.

b. Jika nilai probabiliti $\mathrm{F} \geq \alpha=0,05$, maka digunakan model common effect. Dan jika nilai probabiliti $\mathrm{F} \leq \alpha=0,05$, maka digunakan model fixed effect.

Uji Hausman

Uji hausman digunakan untuk menentukan model mana yang akan digunakan apakah fixed effect atau random effect dalam mengestimasi data panel. Kriteria yang digunakan untuk menarik kesimpulan pada uji hausman adalah :

a. Jika nilai $\mathrm{W}>X^{2}$, maka digunakan model fixed effect. Dan jika nilai $\mathrm{W}<X^{2}$, maka digunakan model random effect.

b. Jika nilai probabiliti $\mathrm{F} \geq \alpha=0,05$, maka digunakan model random effect. Dan jika nilai probabiliti $\mathrm{F} \leq \alpha=0,05$, maka digunakan model fixed effect.

3. Uji Statistik :

a. Uji t Statistik

Uji t dilakukan untuk menguji signifikan dari setiap variabel independen secara parsial dalam mempengaruhi variabel dependen, dalam pengujian digunakan uji dua arah. Hipotesis yang akan diuji adalah :

$\mathrm{HO}: \beta \mathrm{i}=0$, setiap variabel independen tidak signifikan mempengaruhivariabel dependen.

$\mathrm{H} 1$ : $\quad \beta \mathrm{i} \neq 0$, minimal satu variabel independen mempengaruhi variabeldependen.

Pengujian ini dilakukan dengan cara membandingkan nilai thitung daripersamaan regresi dengan nilai kritis dari tabel-t (t-tabel) pada tingkat kepercayaan tertentu. Jika thitung > t-tabel berarti $\mathrm{H}_{0}$ tidak dapat diterima,artinya variabel independen signifikan mempengaruhi variabel dependen, demikian pula sebaliknya jika thitung $<\mathrm{t}$-tabel berarti $\mathrm{H}_{0}$ tidak dapat ditolak,artinya variabel independen tidak signifikan mempengaruhi variabel dependen. Pengujian juga dapat dilakukan dengan menggunakan probability value dengan kriteria tidak menerima HO jika probability valuenya < nilai a.

b. Uji F Statistik

Uji F digunakan untuk menguji pengaruh variabel independen secara bersama-sama terhadap variabel dependen. Pengujian ini didasarkan atas hipotesis nol $\left(\mathrm{H}_{0}\right)$ yang hendak diuji, dengan hipotesis statistik sebagai berikut (Gujarati, 2003):

$\mathrm{H} 0 ; \beta 1=\beta 2=\beta 3 . . .=\beta i=0$, maka variabel independen secara bersama-sama tidak mempengaruhi variabel dependen. 
$\mathrm{H} 1 ; \beta \mathrm{i} \neq 0$, minimal satu variabel independen secara bersama-sama mempengaruhi variabel dependen.

Untuk menguji kedua hipotesis tersebut dilakukan dengan membandingkan nilai $\mathrm{F}$ hitung dan nilai $\mathrm{F}$ tabel. Jika nilai $\mathrm{F}$ hitung $>\mathrm{F}$ tabel maka kitatidak dapat menerima $\mathrm{H}_{0}$ atau dengan kata lain $\mathrm{H}_{1}$ yang menyatakan bahwa semua variabel independen secara bersama-sama mempengaruhi variabel dependen tidak dapat ditolak. Atau pengujian dapat dilakukan dengan menggunakan probability value dengan kriteria tidak menerima $\mathrm{H}_{0}$ jika probability valuenya < nilai a.

c. Penafsiran koefisien Determinasi $\left(\mathrm{R}^{2}\right)$

Koefisien determinasi digunakan untuk mengukur kedekatanhubungan antara variabel independen dengan variabel dependen. $\mathrm{R}^{2}$ menunjukan besarnya proporsi atau persentase variasi variabel dependen yang dapat dijelaskan oleh variabel independen secara simultan. Besarnya $\mathrm{R}^{2}$ berada antara 0 dan $1\left(0<\mathrm{R}^{2}<1\right)$. Hal ini menunjukan bahwa semakinmendekati 1 nilai $\mathrm{R}^{2}$ berarti model tersebut dapat dikatakan baik karenasemakin dekat hubungan antara variabel dependen dengan variabelindependen. Dengan kata lain, semakin mendekati 1 maka variasi dependen hampir seluruhnya dipengaruhi dan dijelaskan oleh variabel independen.

\section{HASIL DAN PEMBAHASAN / DISCUSSION}

\section{Pemilihan Model Penelitian}

Dalam penelitian ini menggunakan model regresi data panel yang terdiri dari tiga model yaitu common effect, fixed effect, dan random effect. Dengan adanya ketiga model tersebut maka diperlukan pemilihan model yang dipilih. Alat uji digunakan untuk memilih antara fixed effect dan common effect digunakan uji chow, sedangkan untuk memilih model antara fixed effec dan random effect digunakan uji hausman.

\section{Uji Chow}

Uji chow dilakukan untuk menentukan model regresi dengan membandingkan common effect dan fixed effect yang dilihat melalui probabilitas chi-square keduanya. Jika nilai probabilitas cross-section kurang dari 0.05, maka menggunakan model fixed effect dan jika nilai probabilitas cross-section lebih dari 0.05, maka menggunakan model common effect. Berdasarkan Tabel 4.2, dapat dilihat bahwa nilai probabilitas cross-section chi-Square sebesar 0.0013 kurang dari taraf signifikan 0.05. Maka dapat disimpulkan dalam pengujian 
chow ini model fixed effect lebih tepat dalam mengestimasi penelitian ini dari pada common effect. Berikut ini adalah tabel estimasi dari uji chow:

Tabel 2

Tabel Uji Chow

Redundant Fixed Effects Tests

Pool: GR

Test cross-section fixed effects

\begin{tabular}{lrrr}
\hline \hline Effects Test & Statistic & d.f. & Prob. \\
\hline \hline Cross-section F & 2.527127 & $(13,53)$ & 0.0089 \\
Cross-section Chi-square & 33.763837 & 13 & 0.0013 \\
\hline \hline
\end{tabular}

Sumber: Hasil olahan E-Views 9, Tahun 2019

Uji Hausman

Uji hausman dilakukan untuk menentukan model regresi dengan membandingkan fixed effect dan random effect yang dilihat melalui probabilitas chi-square keduanya. Jika nilai probabilitas chi-square kurang dari 0.05 maka menggunakan model fixed effect dan jika nilai probabilitas chi-square lebih dari 0.05 maka menggunakan model random effect. Berdasarkan Tabel 4.2, hasil uji hausman menunjukkan bahwa probabilitas chi-Square bernilai 0.0012 Karena nilai probabilitas chi-Square lebih kecil dari 0.05 maka model fixed effect yang terpilih. Maka dari hasil perhitungan dengan regresi sederhana, uji chow dan uji hausman maka model data yang dipilih adalah fixed effect.

Tabel 3

\section{Uji Hausman}

Correlated Random Effects - Hausman Test

Pool: GR

Test cross-section random effects

\begin{tabular}{lccc}
\hline \hline Test Summary & \multicolumn{3}{c}{ Chi-Sq. Statistic Chi-Sq. d.f. Prob. } \\
\hline \hline Cross-section random 15.772199 & 3 & 0.0013 \\
\hline \hline
\end{tabular}

Sumber: Hasil olahan E-Views 9, Tahun 2019

2. Hasil Uji Statistik Analisis Regresi :

a. Uji Signifikan Simultan (Uji F Statistik)

Uji F Statistik digunakan untuk mengetahui pengaruh variabel bebas terhadap variabel terikat secara bersama-sama atau simultan. Berdasarkan pada hasil regresi menunjukkan bahwa nilai probabilitas Uji F Statistik sebesar 0.001186 lebih dari taraf signifikan 0.05 maka dapat disimpulkan bahwa variabel pertumbuhan ekonomi, aglomerasi ekonomi dan modal 
manusia secara bersama memiliki pengaruh yang signifikan terhadap gini rasio di Kabupaten/Kota Provinsi Kalimantan Barat.

b. Koefisien Determinasi $\left(R^{2}\right)$

Uji koefisien determinasi $\left(R^{2}\right)$ digunakan untuk mengukur seberapa besar kemampuan model yang digunakan dalam menjelaskan variasi variabel dependen. Rentang nilai $\mathrm{R}^{2}$ adalah antara $0-1$. Semakin $R^{2}$ mendekati nilai 1 artinya semakin besar variabel-variabel independen dapat menjelaskan variabel dependen.

Berdasarkan pada hasil regresi panel data diketahui bahwa nilai koefisien determinasi $\left(R^{2}\right)$ sebesar 0.478821. Hal ini menunjukkan bahwa persentase perubahan gini rasio Kabupaten/Kota di Provinsi Kalimantan Barat mampu dijelaskan oleh pertumbuhan ekonomi, aglomerasi ekonomi dan modal manusia sebesar 47,88\% sedangkan sisanya sebesar $52,12 \%$ dijelaskan oleh faktor-faktor lain yang tidak digunakan dalam penelitian ini.

c. Pengujian Signifikan Parameter Individual (Uji t Statistik)

Estimasi Model Persamaan Regresi Data Panel

Tabel 4

Estimasi Model Persamaan Regresi Data Panel Pendekatan Fixed Efek Model (REM)

\begin{tabular}{|c|c|c|c|c|}
\hline \multirow{2}{*}{$\begin{array}{c}\text { Variabel } \\
\text { Independent }\end{array}$} & \multicolumn{4}{|c|}{$\begin{array}{l}\text { Variabel Dependent } \\
\text { Gini Rasio }(Y)\end{array}$} \\
\hline & Koefisien & Std.Error & t-stat & P-Value \\
\hline $\mathrm{C}$ & 1.051353 & 0.268672 & 3.913149 & 0.0003 \\
\hline GRW & 0.000614 & 0.005033 & 0.122063 & 0.9033 \\
\hline AGL & -0.000726 & 0.003787 & -0.191694 & 0.8487 \\
\hline $\mathrm{HC}$ & -0.011332 & 0.004238 & -2.673872 & 0.0099 \\
\hline $\mathrm{R}^{2}$ & \multicolumn{4}{|c|}{0.478821} \\
\hline Prob (F-statistic) & \multicolumn{4}{|c|}{0.001186} \\
\hline
\end{tabular}

Sumber: Hasil olahan E-Views 9, tahun 2019

Setelah model persamaan regresi data panel di atas lolos uji chow dan uji hausman. Maka sesuai dengan hasil uji spesifikasi Hausman (Hausman Spesifikasi Test), dapat dilihat hasil penelitian model persamaan regresi data panel untuk mengetahui hubungan antara pertumbuhan ekonomi, aglomerasi dan modal manusia terhadap ketimpangan pendapatan yang dilakukan dengan menggunakan pendekatan fixed effect model(FEM).

Berdasarkan pada nilai konstanta dan koefisien tersebut maka didapatkan persamaan regresi data panel adalah sebagai berikut :

$$
\mathrm{GR}_{i t}=1,051353+0,000614 \mathrm{GRW} \text { it - 0,000726AGLit-0,011332HCit }
$$

Dari tabel hasil estimasi persamaan regresi data panel diatas dengan pendekatan fixed effect model maka diperoleh hasil analisis sebagai berikut :

1. Pengaruh Pertumbuhan Ekonomi Terhadap Ketimpangan Pendapatan 
Hasil penelitian menunjukkan bahwa variabel pertumbuhan ekonomi memiliki pengaruh positif dan tidak signifikan terhadap ketimpangan pendapatan pada daerah Kabupaten/Kota di Provinsi Kalimantan Barat. Ini ditunjukkan dengan nilai probabilitas sebesar 0.9033 lebih besar dari alpa 0,05 persen, yang artinya kenaikan 1 persen pertumbuhan ekonomi akan mengakibatkan peningkatan ketimpangan pendapatan antar Kabupaten/Kota di Provinsi Kalimantan Barat sebesar 0.000614 dengan asumsi variabel aglomerasi dan modal manusia dianggap konstan.

Hal ini sesuai dengan Hipotesis Kuznets, bahwa tahap awal pertumbuhan ekonomi, distribusi pendapatan cenderung memburuk, namun pada tahap selanjutnya, distribusi pendapatan akan membaik, namun pada suatu waktu akan terjadi peningkatan disparitas lagi dan akhirnya menurun lagi (Putri, Amar, \& Aimon, 2015). Pertumbuhan ekonomi berpengaruh terhadap ketimpangan pendapatan dengan arah yang positif. Hal ini mengandung arti bahwa pertumbuhan ekonomi akan meningkatkan jumlah produksi sehingga output juga meningkat. Bertambahnya output akan meningkatkan pendapatan masyarakat dan menambah pendapatan perkapita dan selanjutnya ketimpangan pendapatan antar wilayah akan semakin mengecil (Kurniasih, 2013). Selanjutnya, Alisjahbana (2012) dalam Wibowo (2016) menyatakan bahwa permasalahan ketimpangan pendapatan masyarakat merupakan suatu problem jangka panjang, sehingga untuk memperbaiki ketimpangan pendapatan masyarakat diperlukan strategi dan kebijakan yang lebih baik dan dalam jangka panjang. Dengan berbagai program pengentasan kemiskinan yang telah dilakukan pemerintah untuk meningkatkan kualitas Sumber Daya Manusia (SDM). Dengan semakin meningkatnya kualitas sumber daya manusianya, kesempatan untuk bersaing di pasar kerja semakin meningkat sehingga mampu memiliki tingkat penghasilan yang lebih baik pula.

Hubungan positif dan tidak signifikan yang terjadi antara pertumbuhan ekonomi dengan ketimpangan pendapatan bisa disebabkan karena pertumbuhan ekonomi antar Kabupaten/Kota di Provinsi Kalimantan Barat yang tergolong fluktuatif dan belum terjadi secara merata. Hal ini dapat dijumpai di beberapa Kabupaten/Kota yang memang memiliki pertumbuhan ekonomi yang tinggi seperti Kabupaten Ketapang dengan pertumbuhan ekonomi yang mencapai 7,97 persen tahun 2016 dan turun menjadi 7,21 persen tahun 2017, diikuti Kabupaten Kubu Raya dengan capaian pertumbuhan ekonomi 6,37 persen tahun 2016 dan meningkat menjadi 6,56 persen di tahun 2017. Sedangkan Kabupaten Melawi mempunyai tingkat pertumbuhan ekonomi yang relatif rendah dibandingkan 13 daerah Kabupaten/Kota lainya yaitu sebesar 4,75 persen pada tahun 2016 dan meningkat menjadi 4,79 di tahun 2017. 
Fenomena yang terlihat dari hubungan antara pertumbuhan ekonomi dan ketimpangan pendapatan antar Kabupaten/Kota di Provinsi Kalimantan Barat, menunjukkan bahwa pertumbuhan ekonomi di setiap daerah berdampak kepada ketimpangan pendapatan yang relatif rendah sehingga dapat di gambarkan bahwa untuk daerah Kabupaten/Kota di Provinsi Kalimantan Barat kondisi ketimpangan pendapan relatif tergolong masih rendah atau sedang. Namun dalam hal ini, pertumbuhan yang tinggi bukanlah menjadi satu-satunya syarat untuk mencapai tingkat ketimpangan pendapatan yang rendah pula. Akan tetapi ada kondisi tertentu dimana setiap daerah capaian pertumbuhan ekonominya berbeda-beda antara daerah satu dengan daerah lainnya. Seperti yang di jelaskan oleh Sjafrizal (2017), yang menyatakan bahwa ketimpangan pembangunan yang terjadi ini pada awalnya diakibatkan oleh adanya perbedaan faktor kandungan sumber daya alam dan perbedaan kondisi demografi yang terdapat pada masing-masing wilayah. Akibat dari perbedaan faktor tersebut, menyebabkan kemampuan suatu daerah untuk meningkatkan pertumbuhan ekonomi dan mendorong proses pembangunan juga menjadi berbeda. Oleh karena itu, dalam setiap perkembangannya pada setiap daerah biasanya terdapat wilayah-wilayah yang masuk dalam kategori relatif maju (developed region) dan wilayah relatif terbelakang (underdeveloped region). Pengaruh yang positif dan tidak signifikan antara pertumbuhan ekonomi terhadap ketimpangan pendapatan yang terjadi pada daerah Kabupaten/Kota Provinsi Kalimantan Barat sejalan dengan studi yang dilakukan Arbia (2005), Panizza (2002), Chamber (2010), Kurniawan dan Sugiyanto (2013), Charless-Coll (2013), Wahiba \& El Weriemmi (2014), Turnovsky, (2015), Rubin \& Segal (2015), Hassan, Zaman \& Gul (2015), Yang \& Greaney (2016), Mukhlis, Hidayah dan Sariyani (2018), Pradana, \& Sumarsono (2018), dan Trimurti, et.al (2018)

\section{Pengaruh Aglomerasi Terhadap Ketimpangan Pendapatan}

Hasil penelitian menunjukkan bahwa variabel aglomerasi memiliki pengaruh negatif dan tidak signifikan terhadap ketimpangan pendapatan pada daerah Kabupaten/Kota di Provinsi Kalimantan Barat. Ini ditunjukkan dengan nilai probabilitas sebesar 0.8487 lebih besar dari alpa 0,05 persen, yang artinya kenaikan 1 persen aglomerasi akan mengakibatkan penurunan ketimpangan pendapatan antar Kabupaten/Kota di Provinsi Kalimantan Barat sebesar 0.000726 dengan asumsi variabel pertumbuhan ekonomi dan modal manusia dianggap konstan. Walaupun pengaruhnya tidak signifikan namun nilai koefisiennya sangat kecil sekali dalam mengurangi tingkat ketimpangan pendapatan yaitu sebesar 0,000726, artinya terkonsentrasinya kegiatan ekonomi pada suatu wilayah tidak terlalu berdampak kepada penurunan angka ketimpangan antar Kabupaten/Kota di Provinsi Kalimantan Barat. 
Seperti di ketahui aglomerasi adalah adalah salah satu indikator berkembangnya peranan industri manufaktur di suatu wilayah. Aglomerasi yang cukup tinggi akan menyebabkan pertumbuhan ekonomi daerah cenderung tumbuh lebih cepat. Kondisi tersebut akan mendorong proses pembangunan daerah melalui peningkatan penyediaan lapangan kerja dan tingkat pendapatan masyarakat (Sjafrizal, 2008). Akan tetapi bagi daerah yang memiliki tingkat aglomerasi rendah akan membuat daerah tersebut semakin terbelakang. Selanjutnya Sjafrizal (2008), menjelaskan bahwa terjadinya konsentrasi kegiatan ekonomi yang cukup tinggi pada wilayah tertentu jelas akan mempengaruhi ketimpangan pembangunan antar wilayah. Konsentrasi ekonomi ini tercermin dalam kegiatan aglomerasi.

Walaupun secara langsung variabel aglomerasi ekonomi ini berpengaruh negatif dan tidak signifikan terhadap ketimpangan pendapatan namun secara tidak langsung konsentrasi kegiatan ekonomi ini memberikan dampak terhadap naik turunnya ketimpangan pendapatan antar daerah. Hubungan antara aglomerasi dengan ketimpangan pendapatan antar Kabupaten/Kota di Provinsi Kalimantan Barat dapat dilihat dari besarnya rasio PDRB Kabupaten/Kota terhadap PDRB total di Provinsi Kalimantan Barat cukup bervariasi, hal ini disebabkan kondisi di setiap daerah memiliki keunggulan komparatif yang berbeda pula, seperti perbedaan akan sumber kekayaan alam yang dimiliki oleh setiap daerah, faktorfaktor produksi infrastruktur yang mencakup sarana dan prasarana penunjang serta kemampuan sumber daya manusia yang dimiliki daerah tersebut. Perbedaan ini menyebabkan besarnya rasio PDRB di setiap daerah berbeda sangat signifikan, dan ditunjang dengan peranan atau kontribusi sektoral terhadap total PDRB yang juga berbeda antar Kabupaten/Kota di Provinsi Kalimantan Barat. Selain itu, tingginya nilai tambah produksi terhadap PDRB Provinsi Kalimantan Barat ternyata tidak sejalan dengan besaran pendapatan perkapitanya, dimana PDRB perkapita tertinggi terdapat pada Kota Pontianak dan Kabupaten Ketapang.

Keterkaitan antara konsentrasi kegiatan ekonomi (aglomerasi ekonomi) terhadap ketimpangan pendapatan berdampak kepada penurunan ketimpangan pendapatan yang ada di Kabupaten Kota Provinsi Kalimantan Barat, dimana secara keseluruhan aglomerasi yang terjadi antar Kabupaten/Kota memberikan pengaruh kepada penurunan tingkat ketimpangan pendapatan, walaupun perubahan dari aktivitas terpusatnya kegiatan ekonomi antar daerah tersebut masih relatif rendah atau kecil, dimana daerah-daerah yang aktivitas ekonominya terpusat dan berdampak pada penurunan angka ketimpangan pendapatan yaitu daerah Kabupaten Mempawah, Sanggau, Ketapang, Melawi, Kubu Raya dan Kota Singkawang. Studi dari Samsir \& Rahman (2018), Ha, Minh Nguyen, Le, Dang Nguyen \& Kien-Trung (2019) menyimpulkan bahwa variabel aglomerasi memiliki pola hubungan yang negatif dan tidak 264 
signifikan terhadap ketimpangan pendapatan. Namun penelitian ini berbeda dengan Yusica, Malik, \& Arifin (2018), Mukhlis, Hidayah \& Sariyani (2018), Kurniawan, \& Sugiyanto (2013), Castells-Quintana (2015), yang menyimpulkan bahwa bahwa variabel aglomerasi secara parsial berpengaruh secara positif dan signifikan terhadap Ketimpangan wilayah.

3. Pengaruh Modal Manusia Terhadap Ketimpangan Pendapatan

Hasil penelitian menunjukkan bahwa variabel modal manusia yang diproksi dengan Indeks Pembangunan Manusia (IPM) memiliki pengaruh negatif dan signifikan terhadap ketimpangan pendapatan antar daerah Kabupaten/Kota di Provinsi Kalimantan Barat. Ini ditunjukkan dengan nilai probabilitas sebesar 0.0099 lebih kecil dari alpa 0,05 persen, yang artinya kenaikan 1 poin Indeks Pembangunan Manusia akan mengakibatkan penurunan ketimpangan pendapatan antar Kabupaten/Kota di Provinsi Kalimantan Barat sebesar 0.0113 dengan asumsi variabel pertumbuhan ekonomi dan aglomerasi dianggap konstan. Seperti yang kita ketahui tujuan utama dari pembangunan manusia ini adalah untuk memperbanyak pilihan-pilihan yang dimiliki manusia, dimana hal tersebut tidak mungkin tercapai tanpa adanya kebebasan memilih apa yang mereka inginkan dan bagaimana mereka akan menjalani hidup. Indeks Pembangunan Manusia (IPM) ini terbagi dalam empat dimensi, yakni dimensi kesehatan (angka harapan hidup), tingkat pendidikan yang diukur dari angka melek huruf dan angka harapan sekolah, serta kemampuan daya beli atau purchasing power parity index (PPP). Oleh karena itu, semakin baik nilai Indeks Pembangunan Manusia (IPM), tingkat kesenjangan pendapatan daerah pun semakin rendah. Dan sebaliknya, semakin rendah nilai Indeks Pembangunan Manusia (IPM), maka dapat mengakibatkan tingkat kesenjangan pendapatan yang semakin tinggi.

Dalam penelitian yang dilakukan oleh Alvan (2007), dikatakan bahwa untuk mencapai GDP dan pendapatan perkapita yang lebih tinggi, serta tingkat ketimpangan yang lebih rendah, indeks pembangunan manusia sebaiknya diprioritaskan dalam program pembangunan suatu negara maupun daerah. Tingginya nilai indeks pembangunan manusia ini akan berdampak positif terhadap distribusi pendapatan, sehingga semakin baik nilai indeks pembangunan manusia, maka semakin rendah tingkat kesenjangan pendapatan suatu daerah. Begitu pula sebaliknya, semakin buruk nilai indeks pembangunan manusianya, maka semakin tinggi pula tingkat kesenjangan pendapatannya. Oleh karena itu, untuk menekan tingkat kesenjangan pendapatan di suatu daerah maupun negara, indeks pembangunan manusianya turut perlu diperhatikan.

Peran modal manusia melalui Indeks Pembangunan Manusia (IPM) dapat mempengaruhi tinggi rendahnya tingkat ketimpangan pendapatan antar daerah. Hal ini 
dapat tergambar dari peningkatan IPM yang ada di Kabupaten/Kota Provinsi Kalimantan Barat yang selama 2 tahun terakhir mengalami tren peningkatan dan penurunan pada ketimpangan pendapatan, sebagai contoh beberapa Kabupaten/Kota yang angka IPM nya tinggi dan berdampak pada angka ketimpangan pendapatan yang turun adalah Kabupaten Sambas dengan IPM tahun 2016 sebesar 64.94 poin dan meningkat menjadi 65.92 poin dengan capaian gini rasio sebesar 0,38 turun menjadi 0,31 poin, kemudian diikuti oleh daerah lainnya yang kondisinya sama dengan Kabupaten Sambas, yaitu Kabupaten Landak, Mempawah, Sanggau, Ketapang, Melawi, Kubu Raya, dan Kota Singkatang.

Kondisi Indeks Pembangunan Manusia (IPM) yang tidak merata antar daerah menyebabkan daerah yang IPM-nya lebih tinggi akan memiliki kualitas manusia yang baik sehingga dapat menunjang pembangunan dan sebaliknya. IPM yang tidak merata antar berbagai daerah akan menyebabkan ada daerah yang relatif lebih maju akibat dari kualitas manusianya yang lebih baik dan ada daerah yang relatif tidak maju akibat kualitas manusianya yang rendah. Hal ini akan mendorong tidak seimbangnya pembangunan yang terjadi. Apabila hal ini terus dibiarkan maka ketimpangan pendapatan yang terjadi antar daerah akan semakin melebar.

Dengan demikian modal manusia yang diproksi dengan Indeks Pembangunan Manusia (IPM) berpengaruh positif dan signifikan terhadap ketimpangan pendapatan yang terjadi antar Kabupaten/Kota di Provinsi Kalimanan Barat. Temuan ini sesuai dengan teori human capital yang mengatakan bahwa modal manusia yang dilihat dari aspek pendidikan memiliki pengaruh terhadap pertumbuhan ekonomi dan akan mengurangi disparitas pendapatan sebab faktor pendidikan berperan di dalam meningkatkan produktivitas tenaga kerja. Teori ini menganggap pertumbuhan penduduk ditentukan oleh produktivitas perorangan. Jika setiap masyarakat memiliki pendapatan yang lebih tinggi karena pendidikannya yang tinggi, maka pertumbuhan ekonomi penduduk dapat ditunjang, dengan adanya pertumbuhan ekonomi baik secara langsung maupun tidak langsung akan berpengaruh negatif terhadap ketimpangan pendapatan. Hasil penelitian ini didukung oleh beberapa studi yang pernah dilakukan oleh Samir dan Rahman (2018), Shahabadi, Nemati \& Hosseinidoust (2018), Pradana \& Sumarsono (2018), Lee, J-W, \& Lee, H (2018), Akhmad, Alyas, \& Amir. 2018. Ha, Minh Nguyen, Le, Dang Nguyen \& Kien-Trung (2019) Putri, Amar \& Aimon (2015), dan Thomas (2009), yang menyimpulkan bahwa Indeks Pembangunan Manusia (IPM) berpengaruh negatif dan signifikan terhadap ketimpangan pendapatan. 


\section{KESIMPULAN / CONCLUSION}

Berdasarkan hasil pengujian dan pembahasan mengenai dampak pertumbuhan ekonomi, aglomerasi dan modal manusia terhadap ketimpangan pendapatan antar kabupaten/kota di Provinsi Kalimantan Barat, maka dapat ditarik beberapa kesimpulan. Selama periode penelitian tahun 2013-2017 di daerah Kabupaten/Kota Provinsi Kalimantan Barat terjadi ketimpangan pendapatan yang relatif berfluktuatif dan masih rendah berdasarkan data gini rasio. Variabel pertumbuhan ekonomi berpengaruh positif dan tidak siginifikan, hasil penelitian ini sejalan dengan Charless-Coll (2013), Wahiba \& El Weriemmi (2014), Turnovsky, (2015), Rubin \& Segal (2015), Hassan, Zaman \& Gul (2015), Yang \& Greaney (2016), Mukhlis, Hidayah dan Sariyani (2018), Pradana, \& Sumarsono (2018), dan Trimurti, et.al (2018). variabel aglomerasi berpengaruh negatif dan tidak signifikan, hasil penelitian ini sejalan dengan Samsir \& Rahman (2018), Ha, Minh Nguyen, Le, Dang Nguyen \& Kien-Trung (2019). Namun penelitian ini berbeda dengan Yusica, Malik, \& Arifin (2018), Mukhlis, Hidayah \& Sariyani (2018), Kurniawan, \& Sugiyanto (2013), Castells-Quintana (2015), yang menyimpulkan bahwa bahwa variabel aglomerasi secara parsial berpengaruh secara positif dan signifikan terhadap Ketimpangan wilayah. Sedangkan variabel modal manusia yang di proksi dengan indeks pembangunan manusia (IPM) berpengaruh negatif dan signifikan terhadap ketimpangan pendapatan antar Kabupaten/Kota di Provinsi Kalimantan Barat, hasil penelitian ini sejalan dengan Samir dan Rahman (2018), Shahabadi, Nemati \& Hosseinidoust (2018), Pradana \& Sumarsono (2018), Lee, J-W, \& Lee, H (2018), Akhmad, Alyas, \& Amir. 2018. Ha, Minh Nguyen, Le, Dang Nguyen \& Kien-Trung (2019) Putri, Amar \& Aimon (2015), dan Thomas (2009). Namun secara simultan variabel pertumbuhan ekonomi, aglomerasi dan modal manusia berpengaruh terhadap ketimpangan pendapatan antar Kabupaten/Kota di Provinsi Kalimantan Barat. Dengan demikian, pemerintah daerah diharapkan mampu merumuskan kebijakan pembangunan yang tepat untuk masing-masing kabupaten/kota di Provinsi Kalimantan Barat agar tingkat ketimpangan distribusi pendapatan semakin rendah, dengan cara pemerataan dibidang pembangunan infrastruktur, alokasi investasi di setiap daerah baik PMDN maupun PMA, memperhatikan kualita SDM dan tenaga kerja terdidik sehingga dapat memberikan nilai tambah bagi pembentukan PDRB di masing-masing Kabupaten/Kota, serta penyediaan pelayanan publik agar kesenjangan antar daerah kota dan kabupaten tidak semakin lebar. Tujuan pembangunan tidak semata berorientasi pada mengejar pertumbuhan yang tinggi tetapi juga harus mempertimbangkan pemerataan dan kesejahteraan. Pemerintah perlu mengkaji 
kembali terhadap permasalahan ketimpangan pendapatan yang terjadi antar Kabupaten/Kota akibat adanya aglomerasi ekonomi dengan melakukan distribusi investasi dan transfer teknologi pada wilayah-wilayah yang tertinggal, sehingga kegiatan konsentrasi penduduk di suatu wilayah dapat dihindari dan aktivitas ekonomi yang dilakukan di setiap wilayah dapat memicu peningkatan pendapatan bagi masyarakat. Peran pemerintah dalam meningkatkan kualitas modal manusia atau Indeks Pembangunan Manusia harus lebih diperhatikan secara maksimal, yaitu dengan cara memberikan porsi anggaran pengeluaran pembangunan dibidang pendidikan dan bidang kesehatan yang lebih produktif dan tepat sasaran terutama dalam menciptakan kualitas SDM guna mendorong peningkatan produktivitas penduduk dan tenaga kerja sehingga dapat meningkatkan perekonomian dan pendapatan masyarakat.

\section{DAFTAR PUSTAKA / REFERENCES}

Akhmad, Alyas, \& Amir. 2018. The Effect Of Economic Growth And Income Inequality On Poverty In Indonesia. IOSR Journal of Economics and Finance (IOSR-JEF) e- ISSN: 2321-5933, p-ISSN: 2321-5925. Volume 9, Issue 4 Ver. II (Jul - Aug. 2018), PP 20-26

Alawin, M., Siam, A., \& Al-Hamdi, M. 2013. The relationship between economic growth and income distribution in Jordan, International Management Review, 9(2), 25-26.

Alvan, Arzu. 2007. Forging a Link Between Human Development and Income Inequality: CrossCountry Evidence. Review of Social, Economic and Business Studies, Vol.7/8, 3143.

Amri, Khairul. 2017. Analisis Pertumbuhan Ekonomi dan Ketimpangan Pendapatan : Panel Data 8 Provinsi di Sematera. Jurnal Ekonomi dan Manemen Teknologi, 1(1), 2017, 111.

Arbia. G. Laura de Dominicis. Gianfranco Piras. 2005. Regional Growth and Regional Inequality in EU and Transition Countries: a Spatial Econometric Approach. 45th Congress of the European Regional Science Association 23-27 August 2005. Amsterdam.

Badan Pusat Statistik. PDRB Kabupaten/Kota Provinsi Kalimantan Barat 2013-2017. BPS Kalimantan Barat.

Badan Pusat Statistik. Berbagai Penerbitan. Kalimantan Barat Dalan Angka. BPS Kalimanan Barat.

Badriah, Lilis Siti, Herman Sambodo \& Irma Suryahan. 2006. Ketimpangan Distribusi Pendapatan Dan Faktor-Faktor Yang Mempengaruhinya Di Kabupaten Purbalingga. EKO-REGIONAL, Vol 1, No.2, September 2006. 
Baharuddin, A. H., Ismail, R. A. G., \& Ghani, N. H. M. 2016. Economic growth and disparity issues in income and education: A causal enquiry on ASEAN Countries, Institution and Economies. 8(3), 1-36.

Becker, G. S. and Chiswick, B. R. 1966. Education and the distribution of earnings. American Economic Review 56 (2): 358-369.

Binatli, A. O. 2012. Growth and income inequality: a comparative analysis. Economics Research International.

Bonet, Jaime. 2006. Fiscal Decentralization and Regional Income Disparities: Evidence From The Colombian Experience. The Annals of Regional Science, 2006, vol. 40, issue 3, 661-676.

Charles-Coll, J. A. 2013. The debat over the relationship between income inequality and economic growth: Does inequality matter for growth?. Research in Applied Economics, $5(2), 1-18$.

Castells-Quintana, David. 2015. Concentration of resources and economic development: An empirical overview. REGION, ISSN 2409-5370, European Regional Science Association (ERSA), Louvain-la-Neuve, Vol. 2, Iss. 1, pp. Y17-Y25.

Chambers, D. 2010. Does a rising tide raise all ships? the impact of growth on inequality. Applied Economics Letters, 17(6), 581-586.

Creswell, J. W. 2016. Research Design Pendekatan Metode Kualitatif, Kuantitatif, dan Campuran (Edisi Ke-6). Yogyakarta: Pustaka Pelajar.

Das, S., Sinha, G., \& Mitra, T. K. (2014). Economic growth and income inequality: examining the links in indian economy, Journal of Quantitative Economics, 12(1), 86-95.

North, Douglas. C. 1955. Location Theory and Regional Economic Growth. Journal of Political, Vol. LXIII, pp.243-258.

Frazer, G. 2006. Inequality and Development Across and Within Countries. World Development, 34 (9), 1459-1481.

Ferdinand, Niyimbanira. 2017. Analysis of the Impact of Economic Growth on Income Inequality and Poverty in South Africa: The Case of Mpumalanga Province. International Journal of Economics and Financial Issues, 2017, 7(4), 254261.

Geppert, K., \& Stephan, A. 2008. Regional disparities in the European Union: Convergence and Agglomeration. Regional Science Association International, 87(2), 193-217.

Gujarati, Damodar. 2003. Ekonomimetrika Dasar, Erlangga, Jakarta. 
Hassan, S. A., Zaman K., \& Gul, S. 2015. The relationship between growthinequality-poverty triangle and environmental degradation: unveiing the reality, Arab Economics and Business Journal, 10, 57-71.

Ha, Minh Nguyen, Le, Dang Nguyen, \& Trung-Kien, Pham. 2019. The Impact Of Urbanization On Income Inequality: A Study In Vietnam. Journal of Risk and Financial Management.

Kuncoro, Mudrajad. 2004. Otonomi dan Pembangunan Daerah : Reformasi, Perencanaan, Strategi dan Peluang. Jakarta: Erlangga.

Kurniasih, Erni Panca. 2013. Ketimpangan Wilayah di Provinsi Kalimantan Barat Suatu Kajian terhadap Hipotesis Kuznet. Jurnal Eksos. Volume 9, Nomor 1, Februari 2013. HIm. 36-48. ISSN 1693 - 9093.

Kurniawan, Benedictus Riandoko Adi \& Sugiyanto, FX. 2013. Pengaruh Pertumbuhan Ekonomi, Share Sektor Industri Dan Pertanian Serta Tingkat Jumlah Orang Yang Bekerja Terhadap Ketimpangan Wilayah Antar Kabupaten/Kota Di Jawa Tengah Tahun 2002-2010. Diponegoro Journal Of Economics. Volume 2, Nomor 1, Halaman $1-14$

Kuznets, Simon. 1955. Economic Growth and Inequality. The American Economic Review, Vol 63 (3), pp.247-258.

Lee, Jong-Wha, \& Lee, Hano. 2018. Human Capital And Income Inequality. ADBI Working Paper Series. 810. Tokyo: Asian Development Bank Institute.

Lundberg, M. and Squire, L. 2003. The simultaneous evolution of growth and inequality. The Economic Journal, 113(487), 326-344.

Mincer, J. 1970. The distribution of labor incomes: A survey with special reference to the human capital approach. Journal of Economic Literature 8 (1): 1-26.

Mincer, J. A. 1974. Schooling, Experience, and Earnings. Cambridge, MA: National Bureau of Economic Research.

Mukhlis, I., \& Simanjuntak, T. M. 2016. The Nexus of Economic Factors and Poverty in The Region's Economy. International Journal of Management Science, 7(1), 14-20.

Mukhlis, Imam, Isnawati Hidayah \& Sariyani. 2018. Economic Agglomeration, Economic Growth and Income Inequality in Regional Economies. Economic Journal of Emerging Markets, 10(2) 2018, 205-212.

Nissim, B. D. 2007. Economic growth and its effect on income distribution. Journal of Economic Studies, 34(1), 42-58.

Putri Yosi Eka, Amar, Syamsul \& Aimon, Hasdi. 2015. Analisis Faktor-Faktor Yang Mempengaruhi Pertumbuhan Ekonomi Dan Ketimpangan Pendapatan Di Indonesia. Jurnal Kajian Ekonomi. Vol. 3 No. 6 .

Panizza, Ugo. 2002. Income Inequality and Economic Growth: Evidence from American Data. Journal of Economic Growth. Vol. 7 (1). pp. 25-41. 
Risso, W. A., \& Carrera, E. J. S. 2012. Inequality and economic growth in China, Journal of Chinese Economic and Foreign Trade Studies, 5(2), 80-90.

Rubin, A. and Segal, D. 2015. The effects of economic growth on income inequality in the US. Journal of Macroeconomics, 45, 258-273.

Sabir, Ahmad Erani Yustika, Susilo, Maskie. 2015. Local Government Expenditure, Economic Growth, and Income Inequality in South Sulawesi Province. Journal of Applied Economics and Business. Vol.3, Issue 2-June, 2015, PP.61-73.

Sjafrizal. 2008. Ekonomi Regional Teori dan Aplikasi. Baduose Media. Padang Sumatera Barat.

Sjafrizal. 2017. Ekonomi Wilayah dan Perkotaan. Edisi.1, Cetakan Ke-3. Jakarta : Rajawali Pers.

Sjafrizal. 2018. Analisis Ekonomi Regional dan Penerapannya di Indonesia. Edisi 1. Cetakan Ke-1, Depok : PT. RajaGrafindo Persada.

Samsir, Andi, \& Rahman, Abdul. 2018. Menelusur Ketimpangan Distribusi Pendapatan Kabupaten dan Kota. Jurnal Ecces. Economics, Social, and Development Studies. Volume 5 Nomor1 Ed.Juni 2018 : page : 22- 42 . p-ISSN: 2407-6635 e-ISSN : 25805570 .

Thomas V. 2009. Income disparity and growth. Global Journal of Emerging Market Economies, Volume 1, Issue 1, 1 January 2009, Pages 63-86.

Trimurti, Christimulia Purnama, Komalawati, \& Mertayasa, I Gede Agus. 2018. Determinan Ketimpangan Pendapatan Di Provinsi Bali. Prosiding Sintesa. ISBN: 978-602-53420-0-4.

Turnovsky, S. J. 2015. Economic growth and inequality: the role of public investment, Journal of Economic Dynamic \& Control, 61,204-221.

Wahiba, N. F. and El-Weriemmi, M. 2014. The relationship between economic growth and income inequality. International Journal of Economics and Financial Issues, 4(1):135143.

Wibowo, Tri. 2012. Ketimpangan Pendapatan dan Middle Income Trap Income Inequality and Middle Income Trap. Kajian Ekonomi \& Keuangan Vol. 20 No. 2 (Agustus 2016).

Yang, Y., \& Greaney, T. M. 2016. Economic Growth and Income Inequality in the Asia-Pacific Region: A Comparative Study of China, Japan, South Korea, and the United States, Journal of Asian Economics.

Yusica, Liling Vera, Nazaruddin Malik, dan Arifin, Zaenal. 2018. Analisis Pengaruh Pertumbuhan Ekonomi, Aglomerasi Dan Tingkat Pengangguran Terhadap Ketimpangan Antar Wilayah Kabupaten/Kota Di Provinsi Kalimantan Timur. Jurnal Ilmu Ekonomi Vol 2 Jilid 2/Tahun 2018 Hal. 230 - 240. 